\title{
Mangosteen Peel Extract (Garcinia mangostana L.) and its Constituents to Lower Lipid Content on Adipogenesis Cells Model (3T3-L1)
}

\author{
Wahyu Widowati ${ }^{*}$, Lusiana Darsono ${ }^{1}$, Jo Suherman ${ }^{1}$, Ervi Afifah ${ }^{2}$, Rizal Rizal ${ }^{2}$, Yukko Arinta ${ }^{2}$, \\ Rismawati Laila Qodariah' ${ }^{2}$, Tjandrawati Mozef ${ }^{3}$ and Tri Suciati ${ }^{4}$ \\ ${ }^{1}$ Faculty of Medicine, Maranatha Christian University, Bandung - 40164, Indonesia; wahyu_w60@yahoo.com \\ ${ }^{2}$ Biomolecular and Biomedical Research Center, Aretha Medika Utama, Bandung - 40163, Indonesia \\ ${ }^{3}$ Research Center for Chemistry, Indonesian Institute of Sciences, Bandung, West Java, Indonesia \\ ${ }^{4}$ Faculty of Pharmacy, Bandung Institute of Technology, Bandung, West Java, Indonesia
}

\begin{abstract}
Obesity is one of the risk factor for dyslipidemia incident, cancer, diabetes mellitus, and cardiovascular disease. Treatment of obesity using common commercial drugs shows low rate of success, hence natural products may provide better or more efficient therapeutic approach. Mangosteen (Garcinia mangostana L.) (Clusiaceae) peel extract contains xanthones and it is potentially used as alternative medicine for obesity. This research was done to determine the anti-obesity characteristics of Mangosteen Peel Extract (MPE) and its xanthones $\alpha$-Mangostin (AM) and $\gamma$-Mangostin (GM) on 3T3L1 cell line. Anti-obesity effects of MPE and xanthones were investigated using differentiated-3T3L1 preadipocyte cells. Inhibitory activity of the extract and compounds on the production of Triglyceride (TG), Cholesterol (CHOL), Glucose-6-Phosphate Dehydrogenase (G6PDH) activity, and lipid droplets were examined. MPE and its compound were capable to inhibit the production of TG, CHOL, G6PDH, lipid droplets. MPE $50 \mu \mathrm{g} / \mathrm{mL}$ and GM $75 \mu \mathrm{M}$ were the most active to lower TG $57.95 \%$ and $59.72 \%$, CHOL 33.33\% and 31.68\%, G6PDH 52.90\%, 41.95\%, lipid droplets $72.99 \%$ and $70.07 \%$ respectively. In conclusion mangosteen peel extract and $y$-Mangostin are the most active antiobesity compared to $\alpha$-Mangostin.
\end{abstract}

Keywords: Glucose-6-Phosphate Dehydrogenase, Mangosteen, Obesity, Xanthones, 3T3-L1 Cells

\section{Introduction}

Obesity is a complex disorder that has effects on the normal functions of the body. Obesity is a worldwide threat for public health, as it is involved in various diseases, such as hypertension, coronary heart disease, aosteoarthritis, cancer, type 2 diabetes, and many more ${ }^{1}$. In the first half of $21^{\text {st }}$ century, obesity became one of a great challenge in public health ${ }^{2}$. Many studies to prevent and treat obesity have been conducted ${ }^{3}$. There are many strategies known for effective obesity therapy, some of them are inhibiton of adipocyte differentiation, stimulation of energy expediture, suppression of food intake, regulation on lipid metabolism, and lipase inhibition ${ }^{4}$.

Plants and their active chemical constituents are known to posses activity that can be used in the treatment of obesity. This approach is considered effective as herbal medicine has less toxicity and side effect compared to synthetic drugs ${ }^{5-9}$. Mangosteen (Garcinia mangostana L.) of the family clusiaceae is a tropical tree and mostly found in India, Malaysia, Myanmar, Philippines, Thailand, and other tropical countries. The fruit hull has been used for treatment of many medical conditions and diseases such as skin infection, 
wounds, and amoebeic dysentery in Southeast Asia for hundreds of years ${ }^{10}$. The bioactive metabolites that are mostly found in G. mangostana are xanthone derivates including $\gamma$-Mangostin, $\alpha$-Mangostin, Garcinone-D (Gar-D), Garcinone-C (Gar-C) ${ }^{11}$, 8-deoxygartanin, cudraxanthone $\mathrm{G}$, garcimangosone $\mathrm{B}$, gartanin, 1-isomangostin, garcinone $\mathrm{E}$, smeathxanthone $\mathrm{A}$, tovophyllin A, and mangostinone ${ }^{12}$. Xanthones have been reported for their numerous and varied pharmacological effects, such as antioxidant, antibacterial, antifungal, anti-inflammatory, antihistamine, cytotoxic, Central Nervous System (CNS) depressant or stimulant, anti-HIV, anticancer, antihypertensive, antidiabetic, hepatoprotective, immunomodulation properties, antioxidant, antimicrobial and other activities ${ }^{10,13-15}$. The dominant xanthone found from the G. mangostana fruit hull is $\alpha$-Mangostin, which has been demonstrated by previous pharmacological studies to possess antibacterial, antioxidant, anti-inflammatory, renoprotective and antitumor activities ${ }^{16-21,14}$. Therefore, this study was aimed to evaluate the inhibitory potential of Mangosteen Peel Extract (MPE), $\alpha$-Mangostin (AM), $\gamma$-Mangostin (GM) in adipogenesis cells model (3T3L1) by analyzing the level of Cholesterol (CHOL), Tryglyceride (TG), lipid, and Glucose-6-Phosphate Dehydrogenase (G6PDH) which plays a major role in lipid metabolism.

\section{Materials and Methods}

\subsection{Mangosteen Peel Extraction}

The mangosteen (G. mangostana L.) fruit were obtained from farms in Cisalak-Subang, West Java, Indonesia. The plant was identified by a herbarium staff from Department of Biology in School of Life Science and Technology, Bandung Institute of Technology, Bandung, Indonesia. The peel was collected from mangosteen fruit, then dried and then extracted by maceration with distilled ethanol (70\%). The filtrate was collected after 24 hours this procedure was repeated until the filtrate was colorless. The filtrate was then evaporated with a rotatory evaporator at $40^{\circ} \mathrm{C}$ to yield Mangosteen Peel Extract (MPE). It was stored in $-20^{\circ} \mathrm{C}^{11,14,15}$ until further used.

\subsection{Cell Cultures and Adipogenesis Induction}

The 3T3-L1 cells (ATCC ${ }^{\circledR}$ CL173) were obtained from Aretha Medika Utama, Bimolecular and Biomedical Research Center, Bandung, Indonesia. The cells were grown and then maintained in Dulbecco's Modified Eagle Medum (DMEM) (Gibco, 11995065) which was supplemented with $10 \%$ of Fetal Bovine Serum (FBS) (Gibco, 26140079) and 1\% Antibiotic/Antimycotic (ABAM) (Gibco, 15240-062) then incubated for 24 hours at $37^{\circ} \mathrm{C}$ and $5 \% \mathrm{CO}_{2}$. After cells confluence reached 60 $70 \%$, cells differentiation was induced using Millipore ECM 950 kit. The medium was replaced by initiation medium (DMEM containing Fetal CalfSerum (FCS) 10\%, IBMX (1:1000), dexamethasone (1:10000), 1\% ABAM), and then incubated for 48 hours. The initiation medium was then replaced with progression medium (DMEM supplemented with FBS 10\% and insulin (1:1000), 1\% ABAM and again incubated for 48 hours. The medium used was replaced again with the maintenance medium DMEM supplemented with 10\% FCS (Biowest, S0400$500)$ and then incubated for $4-5$ days in $37^{\circ} \mathrm{C}$ incubator. On the fifth day after differentiation induction, medium was refreshed with DMEM containing 10\% FBS and 1\% $\mathrm{ABAM}^{22,23}$.

\subsection{Measurement of Lipid Acummulation}

Measurement of lipid accumulation was done with Adipogenesis Assay Kit (Merck, ECM950). Differentiated cells were treated with MPE (25 and 50 $\mu \mathrm{g} / \mathrm{ml}), \mathrm{AM}(25$ and $50 \mu \mathrm{M})$, and GM (50 and $75 \mu \mathrm{M})$, and incubated for as long as 24 hours. The medium was discarded, washed with PBS, then added with Oil-red O (Merck, 90358) $500 \mu$ l, incubated for 15-30 minutes. Oil-red $\mathrm{O}$ was removed, and cells were washed with Wash Solution (Merck, 90360). The cells were observed with the inverted light Olympus microscope (Olympus Inverted Microscope CKX41-F32FL). Cells were extracted with Dye Extraction (Merck, 90359) 500 $\mu \mathrm{l}$, incubated in orbital shaker (Labnet, S0600) for 1530 minutes. Dye extraction was transferred into 96-well plate, and absorbance was read at $490 \mathrm{~nm}$ (Multiskan ${ }^{\mathrm{Tm}}$ GO Microplate Spectrophotometer) ${ }^{22-24}$. 


\subsection{Triglyceride (TG) Assay}

The 3T3-L1 adipocytes were harvested 5 days after the initiation of differentiation. The cells were washed twice with cold PBS, collected, and lysed in lysis buffer (1\% Triton X-100 in PBS). The total TG content in the cells was determined with a colorimetric enzymatic test using Glycerol-3-Phospate-Oxidase (GPO) (DiaSys 1576099 10 023). $500 \mu \mathrm{l}$ mixed reaction contained $450 \mu \mathrm{l}$ reagent with five microlitre sample (cell lysate) was incubated in $37{ }^{\circ} \mathrm{C}$ for 5 minutes. The absorbance was measured at $500 \mathrm{~nm}^{15,22}$.

\subsection{Cholesterol (CHOL) Assay}

The cholesterol level of lysed differentiated cells was measured with enzymatic photometric test (DiaSys 113009910 021). Briefly, 5 Hl sample (cell lysate after MPE, AM, GM treatment) was introduced into the sample well which contained $450 \mu$ l reagent, while $5 \mu \mathrm{l}$ of $\mathrm{ddH}_{2} \mathrm{O}$ was used as blank sample, incubated at temperature $37^{\circ} \mathrm{C}$ for 10 minutes. The absorbance was measured at $500 \mathrm{~nm}^{15,22}$.

\subsection{Glucose-6-Phosphate Dehydrogenase Activity Assay}

The differentiated cells were added in 96 well plates $\left(5 \times 10^{3}\right.$ cells/well) in $100 \mu \mathrm{l}$ medium (DMEM containing $10 \% \mathrm{FBS}$ and $1 \% \mathrm{ABAM}$ ) for 24 hours at $37^{\circ} \mathrm{C}$ and $5 \%$ $\mathrm{CO}_{2}$, then assayed using G6PDH kit (Abcam, AB102529). Briefly $50 \mu \mathrm{l}$ reaction mix were added into positive control and sample wells (MPE, AM, GM treatment), while background mix was added into background control wells. Samples were incubated at $37^{\circ} \mathrm{C}$ in dark room. The absorbance of samples was read at $450 \mathrm{~nm}$ after 30 minutes $^{22,24}$.

\subsection{Statistical Data Analysis}

Statistical analysis of the data was evaluated using Statistical Package for the Social Sciences statistics version 17.0 software. Statistical analysis was evaluated by One-way Analysis of Variance (ANOVA). And then analysis was followed by Duncan post-hoc test and was considered to be significant $(\mathrm{p}<0.05)$. Data are presented as mean \pm Standard Deviation.

\section{Results}

\subsection{Effect of MPE, AM, GM on Lipid Accumulation in 3T3-L1 Adipocytes}

Obesity is a disorder of lipid metabolism ${ }^{25}$. To measure the lipid accumulation in obesity model in 3T3-L1, quantified by measuring the Optical Density (OD) at $490 \mathrm{~nm}^{26}$. Lipid accumulation is associated with the development and occurrence of obesity. Lipid accumulation in the adipocytes is a result of a hyperplasia and hypertrophy of adipocyte cells. Inhibition and prevention of accumulation of cytoplasmic lipid droplets and adipogenesis in 3T3-L1 cells that were treated at the differentiation and maintenance stages are shown to reduce lipid accumulation ${ }^{24}$ (Figure 1).

As shown in the Figure 1, treatment of MPE, AM, and GM reduced the lipid accumulation as indicated by lipid droplet compared to differentiated cells (0.7968). MPE of $50 \mu \mathrm{g} / \mathrm{ml}$ showed highest decrease among treated groups. This was also supported with the results of quantitative lipid measurement in which treatment of MPE $50 \mu \mathrm{g} / \mathrm{ml}$ showed the lowest lipid level (0.2153) among treatments (Table 1). Negative control (without treatment) showed no differentiation as indicated by the lipid droplet formation (Figure 1) and lowest of absorbance value (Table 1).

Table 1. Level of lipid in adipocytes (3T3-L1) treated with MPE, AMP, GMP

\begin{tabular}{lc}
\hline \multicolumn{1}{c}{ Samples } & Level of lipid \\
\hline Positive control (Differentiated) & $0.7968 \pm 0.0368^{\mathrm{e}}$ \\
Negative control (Un-differentiated) & $0.1326 \pm 0.0182^{\mathrm{a}}$ \\
MPE $25 \mu \mathrm{g} / \mathrm{ml}$ & $0.3172 \pm 0.0009^{\mathrm{abc}}$ \\
MPE $50 \mu \mathrm{g} / \mathrm{ml}$ & $0.2153 \pm 0.0549^{\mathrm{ab}}$ \\
AM $25 \mu \mathrm{M}$ & $0.5704 \pm 0.09820^{\mathrm{d}}$ \\
AM $50 \mu \mathrm{M}$ & $0.4316 \pm 0.0682^{\mathrm{cd}}$ \\
GM $50 \mu \mathrm{M}$ & $0.3951 \pm 0.0770^{\mathrm{bcd}}$ \\
GM $75 \mu \mathrm{M}$ & $0.2385 \pm 0.0103^{\mathrm{abc}}$ \\
\hline
\end{tabular}

*Data are presented as Mean \pm Standard Deviation. Different supercript letters $(a, a b, a b c, b c d, c d, d, e)$ show significant difference $(p<0.05)$ among treatments (un-differentiated, differentiated cells, MPE, AM, GM treatment) the data was analyzed with Anova and Duncan pos hoc test. 
A

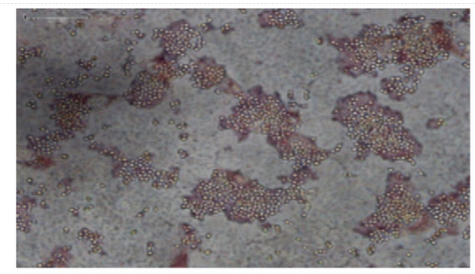

D

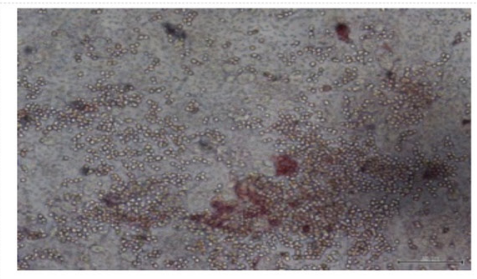

G

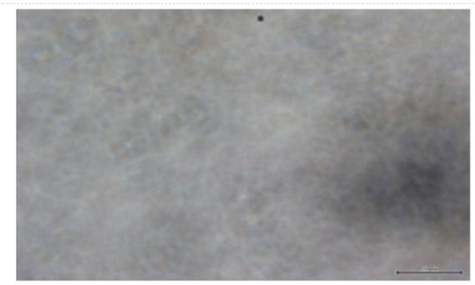

B

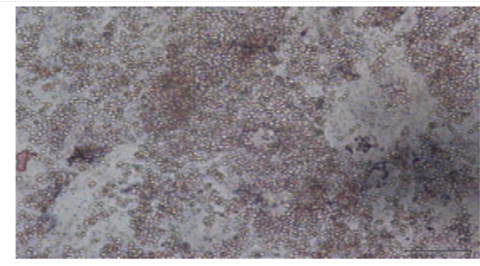

$\mathbf{E}$

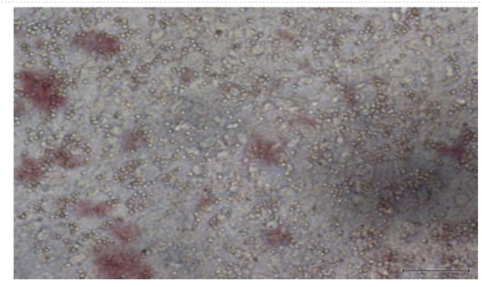

C

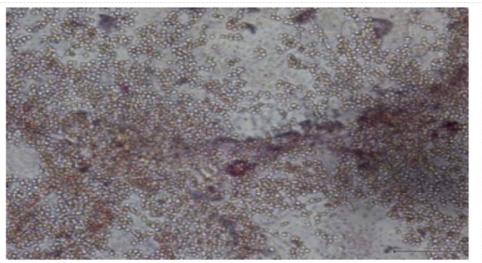

F

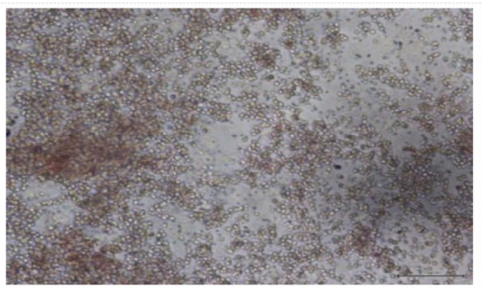

$\mathbf{H}$

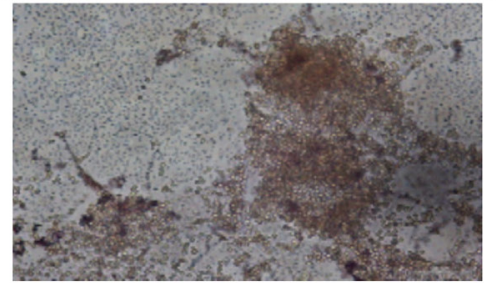

Figure 1. The lipid measurement in 3T3-L1 cells stained after treatment of MPE, AM and GM.

(A) MPE $25 \mu \mathrm{g} / \mathrm{ml}$, lipid accumulation was lower than positive control. (B) MPE $50 \mu \mathrm{g} / \mathrm{mL}$, lipid accumulation was lower than positive control. (C) AM mangostin $25 \mu \mathrm{m}$. (D) AM $50 \mu \mathrm{M}$, lipid accumulation was lower than positive control. (E) GM $50 \mu \mathrm{m}$, lipid accumulation was lower than positive control. (F) GM $75 \mu \mathrm{M}$, lipid accumulation was lower than positive control. (G) Non-differentiated 3T3-L1 cells were not stained by Oil Red O Solution. (H) Differentiated cells (positive control). Most preadipocytes were differentiated 5 days after weaning the cells from induction medium to insulin medium. Lipid accumulation in the differentiated cells can be visualized by Oil Red O Solution staining.

\subsection{Effect of MPE, AM, GM on Cholesterol Level in 3T3-L1 Adipocytes}

Consumption of long-chain saturated fatty acids increases cholesterol level ${ }^{25}$. High level of cholesterol is associated with both degree and distribution of obesity ${ }^{27}$. Induced expression of Lipo-Protein Lipase (LPL) and leptin also play roles in cholesterol reduction ${ }^{28}$. Effect of MPE and xanthones treatment on CHOL level of adipocytes (3T3-L1) is presented in Table 2.

MPE of $50 \mu \mathrm{g} / \mathrm{ml}$ showed the highest inhibitory activity among treatments (33.33\%) with cholesterol level of $177.42 \mathrm{mg} / \mathrm{dl}$. The inhibition activity of MPE was comparable with negative control (29.43\%). However, MPE $50 \mu \mathrm{g} / \mathrm{ml}$ and GM 75 $\mu \mathrm{M}$, have antiobesity potency due to higher $\mathrm{CHOL}$ inhibitory activity (Table 2).
Table 2. Level of cholesterol in adipocytes (3T3-L1) treated with MPE, AM, GM

\begin{tabular}{lcc}
\hline \multicolumn{1}{c}{ Samples } & CHOL (mg/dl) & $\begin{array}{c}\text { Inhibition of CHOL } \\
\text { level } \\
\text { over positive } \\
\text { control (\%) }\end{array}$ \\
\hline $\begin{array}{l}\text { Positive control } \\
\text { (Differentiated) }\end{array}$ & $266.12 \pm 37.95^{\mathrm{b}}$ & $0.00 \pm 14.26^{\mathrm{a}}$ \\
$\begin{array}{l}\text { Negative control } \\
\text { (Un-differentiated) }\end{array}$ & $187.80 \pm 37.38^{\mathrm{a}}$ & $29.43 \pm 14.05^{\mathrm{b}}$ \\
MPE $25 \mu \mathrm{g} / \mathrm{ml}$ & $220.17 \pm 8.67^{\mathrm{ab}}$ & $17.27 \pm 3.26^{\mathrm{ab}}$ \\
MPE $50 \mu \mathrm{g} / \mathrm{ml}$ & $177.42 \pm 32.75^{\mathrm{a}}$ & $33.33 \pm 12.31^{\mathrm{b}}$ \\
AM $25 \mu \mathrm{M}$ & $245.34 \pm 34.79^{\mathrm{ab}}$ & $7.81 \pm 13.07^{\mathrm{ab}}$ \\
AM $50 \mu \mathrm{M}$ & $218.57 \pm 19.95^{\mathrm{ab}}$ & $17.87 \pm 7.50^{\mathrm{ab}}$ \\
GM $50 \mu \mathrm{M}$ & $222.97 \pm 15.27^{\mathrm{ab}}$ & $16.22 \pm 5.74^{\mathrm{ab}}$ \\
GM $75 \mu \mathrm{M}$ & $181.81 \pm 9.08^{\mathrm{a}}$ & $31.68 \pm 3.41^{\mathrm{b}}$ \\
\hline
\end{tabular}

*Data are presented as Mean \pm Standard Deviation. Different superscript letters $(a, a b, b)$ show significant difference $(p<0.05)$ among treatments (un-differentiated, differentiated cells, MPE, AM, GM treatment) in CHOL level and inhibition $\mathrm{CHOL}$ level over positive control show significant difference, the data was analyzed with Anova and Duncan pos hoc test. 


\subsection{Effect of MPE, AM, GM on Triglyceride Level in 3T3-L1 Adipocytes}

Obesity is correlated with high level of $\mathrm{TG}^{29}$. TG in adipose tissue acts as a major energy storage form. Obesity that is associated with adipocyte hypertrophy occurs when TG synthesis exceeds TG breakdown and resulting in elevated TG storage ${ }^{30}$. It was also stated that 3T3-L1 adipocyte cells that is treated with lypolitic substance at differentiation stage ${ }^{24}$. Effect MPE and xanthones treatment on TG level of adipocytes (3T3-L1) can be seen in Table 3 .

Based on Table 3, GM $75 \mu \mathrm{M}$ showed the lowest TG level $(201.90 \mathrm{mg} / \mathrm{dl})$ than GM $50 \mu \mathrm{M}(227.55 \mathrm{mg} / \mathrm{dl})$, MPE $50 \mu \mathrm{g} / \mathrm{ml}(210.76 \mathrm{mg} / \mathrm{dl})$ and were also comparable with negative control $(195.37 \mathrm{mg} / \mathrm{dl})$. This data is in line with inhibitory activity of TG of GM $75 \mu \mathrm{M}(59.72 \%)$, GM $50 \mu \mathrm{M}(54.60 \%)$, MPE $50 \mu \mathrm{g} / \mathrm{ml}$ (57.95\%). However, MPE $50 \mu \mathrm{g} / \mathrm{ml}$, GM $75 \mu \mathrm{M}$, GM $50 \mu \mathrm{M}$ has antiobesity potency due to higher TG inhibitory activity (Table 3 ).

Table 3. Level of triglyceride in adipocytes (3T3-L1) treated with MPE, AM, GM

\begin{tabular}{lcc}
\hline \multicolumn{1}{c}{ Samples } & TG (mg/dl) & $\begin{array}{c}\text { Inhibition of TG } \\
\text { level over positive } \\
\text { control (\%) }\end{array}$ \\
\hline $\begin{array}{l}\text { Positive control } \\
\text { (Differentiated) }\end{array}$ & $501.26 \pm 35.69^{\mathrm{c}}$ & $0.00 \pm 7.12^{\mathrm{a}}$ \\
$\begin{array}{l}\text { Negative control (Un- } \\
\text { differentiated) }\end{array}$ & $195.37 \pm 15.41^{\mathrm{a}}$ & $61.02 \pm 3.07^{\mathrm{c}}$ \\
MPE $25 \mu \mathrm{g} / \mathrm{ml}$ & $286.30 \pm 10.68^{\mathrm{b}}$ & $42.88 \pm 2.13^{\mathrm{b}}$ \\
MPE $50 \mu \mathrm{g} / \mathrm{ml}$ & $210.76 \pm 24.12^{\mathrm{a}}$ & $57.95 \pm 4.81^{\mathrm{c}}$ \\
AM $25 \mu \mathrm{M}$ & $316.14 \pm 17.27^{\mathrm{b}}$ & $36.93 \pm 3.44^{\mathrm{b}}$ \\
AM $50 \mu \mathrm{M}$ & $296.09 \pm 14.56^{\mathrm{b}}$ & $40.93 \pm 2.90^{\mathrm{b}}$ \\
GM $50 \mu \mathrm{M}$ & $227.55 \pm 24.64^{\mathrm{a}}$ & $54.60 \pm 4.92^{\mathrm{c}}$ \\
GM $75 \mu \mathrm{M}$ & $201.90 \pm 4.85^{\mathrm{a}}$ & $59.72 \pm 0.97^{\mathrm{c}}$ \\
\hline
\end{tabular}

${ }^{*}$ Data are presented as Mean \pm Standard Deviation. Different superscript letters $(a, b, c)$ show significant difference $(p<0.05)$ among treatments (un-differentiated, differentiated cells, MPE, AM, GM treatment) in TG level and inhibition TG level over positive control show significant difference, the data was analyzed with Anova and Duncan pos hoc test.

\subsection{Effect MPE, AM, GM on G6PDH Level in 3T3-L1 Adipocytes}

$\mathrm{G6PDH}$ is responsible in adipogenesis by generating ligand Peroxisome Proliferator-Activated Receptor $\gamma$ $(\operatorname{PPAR} \gamma)$ activating adipocyte-specific gene expression and differentiation, as well as regulating adipose tissue mass which is associated with obesity development ${ }^{31}$. Effect MPE and xanthones treatment on G6PDH level of adipocytes (3T3-L1) can be seen Table 4.

Table 4. Level of G6PDH in adipocytes (3T3-L1) treated with MPE, AM, GM

\begin{tabular}{lcc}
\hline \multicolumn{1}{c}{ Samples } & $\begin{array}{c}\text { G6PDH level } \\
\text { (nmol/min/ } \\
\text { ml) }\end{array}$ & $\begin{array}{c}\text { Inhibition of G6PDH } \\
\text { over positive control } \\
(\%)\end{array}$ \\
\hline $\begin{array}{l}\text { Positive control } \\
\text { (Differentiated) }\end{array}$ & $0.79 \pm 0.03^{\mathrm{f}}$ & $0.00 \pm 4.41^{\mathrm{a}}$ \\
$\begin{array}{l}\text { Negative control } \\
\text { (Undifferentiated) }\end{array}$ & $0.33 \pm 0.02^{\mathrm{a}}$ & $57.84 \pm 2.00^{\mathrm{f}}$ \\
MPE $25 \mu \mathrm{g} / \mathrm{ml}$ & $0.53 \pm 0.03^{\mathrm{cde}}$ & $32.69 \pm 3.45^{\mathrm{bcd}}$ \\
MPE $50 \mu \mathrm{g} / \mathrm{ml}$ & $0.37 \pm 0.06^{\mathrm{ab}}$ & $52.90 \pm 8.09^{\mathrm{de}}$ \\
AM $25 \mu \mathrm{M}$ & $0.63 \pm 0.02^{\mathrm{e}}$ & $20.28 \pm 3.10^{\mathrm{b}}$ \\
AM $50 \mu \mathrm{M}$ & $0.52 \pm 0.01^{\mathrm{cd}}$ & $34.46 \pm 1.83^{\mathrm{cd}}$ \\
GM $50 \mu \mathrm{M}$ & $0.59 \pm 0.06^{\mathrm{de}}$ & $25.24 \pm 7.10^{\mathrm{bc}}$ \\
GM $75 \mu \mathrm{M}$ & $0.46 \pm 0.05^{\mathrm{bc}}$ & $41.95 \pm 5.71^{\mathrm{de}}$ \\
\hline
\end{tabular}

*Data are presented as Mean \pm Standard Deviation. Different superscript letters $(a, a b, b c, c d, c d e, d e, e, f)$ show significant difference $(p<0.05)$ among treatments (un-differentiated, differentiated cells, MPE, AM, GM treatment) in G6PDH level and inhibition G6PDH level over positive control show significant difference, the data was analyzed with Anova and Duncan pos hoc test.

In G6PDH level, MPE $50 \mu \mathrm{g} / \mathrm{ml}$ showed the lowest level $(0.37 \mathrm{nmol} / \mathrm{min} / \mathrm{ml})$, this result was comparable with negative control $(0.33 \mathrm{nmol} / \mathrm{min} / \mathrm{mL})$. MPE 50 $\mu \mathrm{g} / \mathrm{ml}$ also showed the highest inhibitory activity of G6PDH among treatments (52.90\%), and this data was comparable with negative control (57.84\%). However, MPE of $50 \mu \mathrm{g} / \mathrm{ml}$ has antiobesity potency due to higher G6PDH inhibitory activity (Table 4).

\section{Discussion}

Obesity is a disorder which involves lipid metabolism and the enzymes that are involved in this process can be targeted to develop various antiobesity drugs. Xanthones from G. mangostana have antiobesity activity through anti-adipogenic, anti-inflammatory, antioxidant activities $^{29}$. $\alpha$-Mangostin attenuated TNF- $\alpha$ and IL-8 secretion by the various cell lines activated macrophage including THP-1, hepatic HepG2, enterocyte-like Caco2, and colon HT-29 primary human Monocyte-Derived Macrophages $(\mathrm{MDM})^{32}$, mangosteen peel extract and its constituents $\alpha$-Mangostin, and $\gamma$-Mangostin possess 
the anti-inflammatory effect by reducing COX-2, IL6 , IL-1 $\beta$, and NO production in LPS-induces RAW 264.7 cells $^{14}$. Mangosteen peel and its compound have high antioxidant activities ${ }^{33}$. $\alpha$-Mangostin can suppress intracellular lipid accumulation in differentiating adipocytes and stimulated lipolysis in mature adipocytes; inhibit Fatty Acid Synthase (FAS) $)^{34}$. Mangosteen peel extract and its constituents have antiinflammatory, antioxidant, antiadipogenesis and these mechanism can be useful in treating or preventing obesity ${ }^{34}$.

Lipid-lowering activity of MPE, and its constituents (Table 1), is caused by the inhibition of the transcriptional regulation of lipid synthesis and/or stimulation of lipolysis in 3T3-L1 adipocytes ${ }^{35}$. The differentiation of preadipocytes into adipocytes is regulated by a complex network of transcription factors. After differentiation, $\mathrm{C} / \mathrm{EBP} \beta$ was induced immediately, while $\mathrm{C} / \mathrm{EBP} \alpha$ and PPAR $\gamma$ are master regulators of adipogenesis; their maintenance is critical to the progression of the final stages of adipocyte differentiation ${ }^{36,37}$. Adipocyte differentiation and fat accumulation are associated with the occurrence and development of obesity ${ }^{38}$. Increase in the number of fat cells and adipose tissue mass further cause obesity.

Theoretically, the higher the lipid droplets formation the higher the optical density and therefore, the plants with more formation of lipid droplets results higher absorbance which would be effective in the induction of differentiation of pre-adipocyte to adipocyte. Control (without treatment) showed no differentiation as indicated by the lipid droplet formation and absorbance reading. There was significant difference for undifferentiated cells compared with the control (differentiated cells) $)^{39}$.

In this study, MPE and its constituents decreased CHOL level compared to positive control (Table 2). The consumption of long-chain saturated fatty acids $(\mathrm{C}>10)$ has led to increase in TG and CHOL levels ${ }^{25,40}$. Furthermore, high TG level leads to increase in Very Low Density Lipoprotein (VLDL) and chylomicron levels, as transporters of TG. LDL is the last stage of VLDL catabolism, therefore raised VLDL levels also increase LDL levels. LDL is responsible for transporting the cholesterol to peripheral tissues for oxidation or to adipose tissues for storage ${ }^{41}$.

High plasma TG is associated with obesity ${ }^{29}$. In the current study, MPE reduced TG level in 3T3-L1.
Metabolism of TG is activated by the expression of adipocyte-specific fatty acid binding protein (aP2), Fatty Acid Synthase (FAS), and Acetyl-CoA Carboxylase (ACC) genes. The decrease of TG content may be resulted from decreasing lipid synthesis. MPE also decreased level of G6PDH which plays a role in adipogenesis through generating ligand Peroxisome Proliferator-Activated Receptor $\gamma$ (PPAR $\gamma)$ which contributes to activation of adipocyte-specific gene expression and differentiation and there by controls energy accumulation in the form of adipose tissue mass which is associated with obesity development ${ }^{31}$. These results suggest that MPE has anti-adipogenesis effect. MPE caused the lowest body weight gain percentage as well as the lowest FAS concentration in adipose tissue and serum of experimental rats. Antiobesity potency of MPE might strongly relate to its $\alpha$-Mangostin content (29.13\%) based on HPLC assay ${ }^{42}$. Based on study of Adnyana et al., (2015), MPE has antiobesity activity higher than AM due to $a$-amylase and pancreatic lipase inhibitory activities ${ }^{43}$.

In this study, MPE showed good activity compared to marker compounds, AM and GM. Many studies have reported beneficial properties of MPE toward the lipid profile. A study carried by Adiputro et al., (2013) revealed that the ethanolic extract of mangosteen pericarp reduced total CHOL, TG, and LDL levels along with increased High-Density Lipoprotein (HDL) levels in rats fed high-lipid diet. There were several compounds of xanthones involved in the stimulation of adipolysis in differentiated 3T3-L1 and primary human adipocytes. Several studies reported that $\alpha$-Mangostin plays a role in reducing lipid accumulation with decreased peroxisome proliferator activated PPAR $\gamma$ expression along with stimulation of the glucose uptake and free fatty acid release from 3T3-L1 adipocytes via GLUT4 and leptin expression ${ }^{44}$. Mangosteen and its xanthones have good potential to control and modify the metabolic syndrome and its related disorders such as obesity, disrupted lipid profile, diabetes and its complications ${ }^{45}$.

\section{Conclusion}

Mangosteen peel extract, and its constituents reduced the levels of lipid, cholesterol, triglyceride, and G6PDH which makes it as a promising antiobesity agent. 


\section{References}

1. Visscher T, Seidell J. The public health impact of obesity. Annu Rev Public Health. 2001; 22:355-75. Crossref. PMid:11274526

2. WHO. The Asia-Pasific perspective: Redefining obesity and its treatment Australia. Health Communications Australia Pty; 2000.

3. Deshpande M, Shengule S, Apte K, Wani M, Piprode V, Parab P. Anti-obesity activity of Ziziphus mauritiana: A potent pancreatic lipase inhibitor. Asian J Pharm Clin. 2013; 6(2):168-73.

4. Yun J. Possible anti-obesity therapeutic from nature-a review. Phytochem. 2010; 71(14-15):1652-41. Crossref. PMid:20732701

5. Gulati V, Harding I, Palombo E. Enzyme inhibitory and antioxidant activities of traditional medicinal plants: potential application in the management of hyperglycemia. BMC Complement Altern Med. 2012; 12:1-9. Crossref. PMid:22713130 PMCid:PMC3502323

6. Rai P, Rai N, Rai A, Watal G. Role in LIBS elemental analysis of $P$. guajava responsible for glycemic potential. Inst Sci Tech. 2007; 35(2007):507-22. Crossref.

7. Sivangasari S, Vijayanand N, Rathinavel S. Antidiabetic activity of Cynodon dactylon (L.) Pers. extract in alloxan induced rats. Int J Pharm Pharm Sci. 2014; 6(4):1-5.

8. Yeh G, Etsenberg D, Kaptchuk T, Philips S. Systematic review of herbs and dietary supplements for glycemic control in diabetes. Diabetes Care. 2003; 26(4):1277-94. Crossref. PMid:12663610

9. Haddad P, Azar G, Groom S, Boivin M. Natural health product, modulation of immune function and prevention of chronic diseases. J Evid Based Complementary Altern Med. 2005; 2(4):513-20. Crossref. PMid:16322809 PMCid:PMC1297498

10. Pedraza-Chaverri J, Cardenas-Rodriguez N, OrozcoIbarra M, Perez-Rojas J. Medicinal properties of mangosteen (Garcinia mangostana). Food Chem Toxicol. 2008; 46(10):3227-39. Crossref. PMid:18725264

11. Widowati W, Darsono L, Suherman J, Yelliantty Y, Maesaroh M. High Performance Liquid Chromatography (HPLC) analysis, antioxidant, antiaggregation of mangosteen peel extract (Garcinia mangostana L.). Int J Biosci Biochem Bioinfo. 2014; 4(2014):458-66. Crossref.

12. Jung HA, Su BN, Keller WJ, Mehta RG, Kinghom AD. Antioxidant xanthones from the pericarp of Garcinia mangostana (mangosteen). J Agric Food Chem. 2006; 54(6):2077-82. Crossref. PMid:16536578
13. Pinto MM, Sousa ME, Nascimento MS. Xanthone derivatives: New insights in biological activities. Curr Med Chem. 2005; 12(21):2517-38. Crossref. PMid:16250875

14. Widowati W, Darsono L, Suherman J, Fauziah N, Maesaroh M, Erawijantari PP. Anti-inflammatory Effect of mangosteen (Garcinia mangostana L.) peel extract and its compounds in LPS-induced RAW 264.7 Cells. Nat Prod Sci. 2016; 22(2016):147-53. Crossref.

15. Darsono L, Hidayat M, Maesaroh M, Fauziah N, Widowati W. Ex vivo study of Garcinia mangostana L. (mangosteen) peel extract and xanthones as anti-adipogenesis in HepG2 cell model. Int J Med Res Health Sci. 2015; 4(3):566-71. Crossref.

16. Obolskiy D, Pischel I, Siriwatanametanon N, Heinrich M. Garcina mangostana L.: A phytochemical and pharmacological review. Pyhtother Res. 2009; 23(8):104765. Crossref. PMid:19172667

17. Lobstein T, Leach R. Tackling obesities: Future choicesinternational comparisons of obesity trends, determinats and responses-evidence review, adults. London: UK Goverment Office for Science; 2007.

18. Lobstein T, Baur L, Uauy R. Obesity in children and young people: A crisis in public health. Obesity Rev. 2014; 5(1):4-85.

19. WHO. Reducing risks, promoting healthy life Geneva: World Health Organization; 2005.

20. Sakagami Y, Ilnuma M, Piyasena K, Dharmaratne H. Antibacterial activity of alpha-Mangosteen against Vancomycin Resistant Enterococci (VRE) and synergism with antibiotics. Phytomed. 2005; 12(3):203-8. Crossref. PMid:15830842

21. Franco M, Ordunez P, Caballero B. Impact of energy intake, physical activity, and population-wide weight loss on cardiovascular disease and diabetes mortality in Cuba, 1980-2005. Am J Epidemiol. 2007; 166(12):1374-80. Crossref. PMid:17881386

22. Hidayat M, Soeng S, Prahastuti S, Erawijantari PP, Widowati W. Inhibitory potential of ethanol extract of Detam 1 soybean (Glycine max) seed and Jati belanda (Guazuma ulmifolia) leaves on adipogenesis and obesity models in 3T3-L1 cell line. Inhibitory potential of ethanol extract of Detam 1 soybean (Glycine max) seed and Jati belanda. J Sci Res Rep. 2015; 6(4):305-12.

23. Hidayat M, Prahastuti S, Fauziah N, Maesaroh M, Balqis $\mathrm{B}$, Widowati W. Modulation of adipogenesis-related gene expression by ethanol extracts of Detam 1 soybean and Jati belanda leaf in 3T3-L1 cells. Bangladesh J Pharmacol. 2016; 11(3):697-702. Crossref. 
24. Mutai E, Sunkara R, Vizcarra J, Walker LT, Verghese M. Antioxidant, enzyme inhibitory andanti-obesity potential of sorrel calyx extracts in 3T3-L1 adipocytes. Food and Nutrition Sciences. 2015; 6(5):452-65. Crossref.

25. Lee YJ, Choi DH, Cho GH, Kim JS, Kang DG, Lee HS. Arctium lappa ameliorates endothelial dysfunction in rats fed with fat/cholesterol diet. BMC Compl Alternative Med. 2012; 12:116. Crossref. PMid:22866890 PMCid:PMC3517347

26. Park MY, Sung MK. Carnosic acid inhibits lipid accumulation in 3T3-L1 adipocytes through attenuation of fatty acid desaturation. J Cancer Prev. 2015; 20(1):41-9. Crossref. PMid:25853102 PMCid:PMC4384713

27. Rashid S, Genest J. Effect of obesity on high-density lipoprotein metabolism. Obesity (Silver String). 2007; 15(12):2957-88. Crossref.

28. Kim EJ, Lee HI, Chung KJ, Noh YH, Ro Y, Koo JH. The Ginsenoside-Rb2 lowers cholesterol and triacylglycerol levels in 3T3-L1 adipocytes cultured under high cholesterol or fatty acids conditions. BMB Reports. 2008; 42:194-9. Crossref.

29. Lei F, Zhang X, Wang W, Xing D, Xie W, Su H, et al. Evidence of anti-obesity effects of promegranate leaf extract in high-fat diet induced obese mice. Int J Obesity. 2007; 31(6):1023-9. Crossref. PMid:17299386

30. Ahmadian M, Duncan RE, Jaworski K, SarkadiNagy E, Sul HS. Triacylglycerol metabolism in adipose tissue. Future Lipidol. 2007; 2(2):229-37. Crossref. PMid:19194515 PMCid:PMC2633634

31. Stern JS, Peerson J, Mishra AT, Rao MV, Rajeswari KP. Efficacy and tolerability of a novel herbal formulation for weight management. Obesity. 2013; 21(5):921-7. Crossref. PMid:23784895

32. Gutierrez-Orozco F, Chitchumroonchokchai C, Lesinski GB, Suksamrarn S, Failla ML. a-Mangostin: anti-inflammatory activity and metabolism by human cells. J Agric Food Chem. 2013; 61(16):3891-900. Crossref. PMid:23578285 PMCid:PMC3793015

33. Tjahjani S, Widowati W, Khiong K, Suhendra A, Tjokropranoto R. Antioxidant properties of Garcinia mangostana L. (mangosteen) Rind. Procedia Chem. 2014; 13(2014):198-203. Crossref.

34. Ibrahim MY, Hashim NM, Mariod AA, Mohan S, Abdulla MA, Abdelwahab SI, et al. a-Mangostin from Garcinia mangostana Linn: An updated review of its pharmacological properties. Arabian J Chem. 2016 May; 9(3):317-29. Crossref.
35. Oppi-Williams C, Suagee JK, Corl BA. Regulation of lipid synthesis by liver $\mathrm{X}$ receptor $\alpha$ and sterol regulatory element-binding protein 1 in mammary epithelial cells. J dairy Sci. 2013; 96(1):112-21. Crossref. PMid:23102957

36. Christy RJ, Kaetner KH, Geiman DE, Lane MD. CCAAT/ enhancer binding protein gene promoter: binding of nuclear factors during differentiation of 3T3-L1 preadipocytes. Proc Natl Acad SciUSA. 1991; 15(6):2593-7. Crossref.

37. Tamori Y, Masugi J, Nishino N, Kasuga M. Role of peroxisome proliferator-activated receptor-gamma in maintenance of the characteristics of mature 3T3-L1 adipocytes. Diabetes. 2002; 51(7):2045-55. Crossref. PMid:12086932

38. Feve B. Adipogenesis: cellular and molecular aspects. Best Pract Res Clin Endocrinol Metab. 2005; 19(4):483-99. Crossref. PMid:16311213

39. Khattaka MM, Taher M, Ichawan SJ, Azaharia N. Selected herbal extracts improve diabetes associated factors in 3T3-L1 adipocyte. Procedia -Soc Behavioral Sci. 2013; 91:357-75. Crossref.

40. Silva MA, Vechetti-Junior IJ, do Nascimento AF, Furtado KS, Azevedo L, Ribeiro DA, et al. Effects of swim training on liver carcinogenesis in male Wistar rats fed a low-fat or high-fat diet. Appl Physiol Nutr Metab. 2012;37(6):1101-9. Crossref. PMid:22957766

41. Lagrost L, Gambert P. HDL and reverse cholesterol transport. Role of cholesterol ester transfer protein. C R Seances Soc Biol Fil. 1992; 186(4):405-13. PMid:1301229

42. Abuzaid AS, Iskandar EY, Kurniati NF, Adnyana IK. Preventive effect on obesity of mangosteen (Garcinia mangostana L.) pericarp ethanolic extract by reduction of fatty acid synthase level in monosodium glutamate and high-calorie diet-induced male wistar rats. Asian J Pharm Clin Res. 2016; 9.

43. Adnyana IK, Abuzaid AS, Iskandar EY, Kurniati NF. Pancreatic lipase and $\alpha$-Amylase inhibitory potential of mangosteen (Garcinia mangostana Linn.) pericarp extract. Int J Med Res Health Sci. 2016; 5:257-60.

44. Taher M, Amiroudine MZ, Zakaria TM, Susanti D, Ichwan SJ, Kaderi MA, et al. $\alpha$-Mangostin improves glucose uptake and inhibits adipocytes differentiation in 3T3-L1 cells via PPAR $\gamma$, GLUT4, and leptin expressions. Evid-Based Complementary Altern Med. 2015; 2015:1-9. Crossref. PMid:25873982 PMCid:PMC4385643

45. Shandiz HT, Razavi BM, Hosseinzadeh H. Review of Garcinia mangostana and its Xanthones in metabolic syndrome and related complications. Phytother Res. 2017; 31(8):1173-82. Crossref. PMid:28656594 